\title{
居住地域における風車騒音の暴露状況の現状
}

\author{
福 島 昭 則 \\ 株式会社ニューズ環境設計
}

\section{Immission Assessments of Wind Turbine Noise in Residential Areas around Wind Farms}

\author{
Akinori FUKUSHIMA \\ NEWS Environmental Design, Inc.
}

\begin{abstract}
Since the large-scale construction of wind power facilities in Japan, serious complaints have arisen from residents regarding wind turbine noise (WTN). However, there was insufficient scientific background to assess this issue. To address this situation, several research projects have been conducted by the Ministry of the Environment, Government of Japan. In this paper, we report actual WTN field measurements for these projects. The $L_{\text {Aeq }}$ values of WTN ranged from 25 to $50 \mathrm{~dB}$ in residential areas. On the other hand, the residual noise levels in control areas with similar local characteristics to the wind farm areas but not affected by WTN ranged from 20 to $35 \mathrm{~dB}$. Thus, there was a notable difference between WTN and residual noise. Wind power facilities are often constructed in quiet, rural districts. With regards to WTN, $L_{\text {Aeq }}$ of noise caused by wind turbines as well as the increase in the overall noise level are important. The measurements of spectral characteristics of WTN were compared against the criterion curve to assess low-frequency noise. As a result, infrasound (frequency components below $20 \mathrm{~Hz}$ ) for all measured WTN values in the residential (immission) areas were found to be much lower than the corresponding values on the criterion curve. In addition, amplitude modulation (AM) sound (also referred to as "swish sound") is often associated with WTN, and can cause serious discomfort to nearby residents. The actual situation with regard to AM sound in residential areas located near wind farms was clarified by field measurements.
\end{abstract}

Key words: wind turbine noise (風車騒音), environmental noise (環境騷音), residual noise (残留騒音), infrasound（超低周波音), amplitude modulation sound（振幅変調音）

\section{1.はじめに}

風車騷音は，道路交通騒音等の交通騒音問題に比べる と歴史は浅く，苦情が寄せられだした 2000 年頃実態も よく分かっていなかった。また居住地域に打ける風車騷 音の測定方法や評価方法もなかった。そのため, 当初は 「騒音に係る環境基準（以下，「環境基準」）」（1）打よび，

受付 2018 年 3 月 22 日，受理 2018 年 5 月 11 日

Reprint requests to: Akinori FUKUSHIMA

NEWS Environmental Design, Inc., 2-2-22 Mizukidori, Hyogo-ku, Kobe 652-0802, Japan

FAX: +81(78)578-8221

E-mail: fuku-new@wonder.ocn.ne.jp
その測定マニュアル（2）により対応がなされることが多 かった。しかしながら，風力発電施設の多くは山間部や 沿岸部の静穏な場所に建設されることが多く, 環境基準 の地域類型が指定されていない場所が多い。そのような 地域に扮ける騒音を環境基準で評価することへの疑問も あった。

そのような状況を踏まえ，環境省に打いて風車騒音に 関する戦略指定研究 I $(3,4)$ および I (5) が実施され, その成果を踏まえて，2016年に「風車騒音に関する指 針值（以下，「指針值」）」（6）が，また 2017 年に風車騒 音の評価のための「風車騒音の測定マニュアル(以下，「測 定マニュアル」)」（7）が公表された。ここでは, ふたつ の戦略指定研究で得られた騒音環境の実態に関する結果 
とその後の調査結果を整理して, 居住地域に抢ける風車 騒音の実態について報告する。

\section{2. 現地調査の概要}

戦略指定研究 I では, 北海道から沖縄県に至る合計 34 の風力発電施設周辺地域を調査対象とし, 各施設に ついて, 風車近傍 1 点, 周辺の居住地域 7 点の測定を行っ ている。また, あわせて地域特性が風車地域と類似し, 風車騒音の影響を受けていない16の対照地域について も同様の実測調査を行っている。

戦略指定研究 II では, 戦略指定研究 I で調査した風力 発電施設がある鹿児島県の島嶼部を対象とし, 風力発電 施設周辺の居住地域から風車から数 $\mathrm{km}$ 離れた風車騒音 の影響を受けない一般の居住地域まで, のべ 72 地点に 扣いて環境騒音の実態調査を行っている

測定には $1 \mathrm{~Hz} \sim 20 \mathrm{kHz}$ を測定対象とする録音機能を 有する広帯域の音圧レベル計を用い, マイクロホンに風 が当たり発生する風雑音を防ぐために二重のウインドス クリーンを使用している $(3,4)$ 。

分析に扣いては，レベル記録と実音モニタリングによ り自動車走行騒音などの測定対象ではない騒音の発生時 間部分を除外音処理し等価騷音レベル $L_{\text {Aeq,10min }}$ を求め, 基準時間帯の $L_{\text {Aeq,night }}$ などを算出している。

\section{3. 風車地域と対照地域の騒音の測定例}

\subsection{1 風車地域での測定例}

風力発電施設の近傍と周辺の居住地域に打液間 の風車騒音の測定例を図 1 に示す $(8)$ 。風車の定格出 力は $1,950 \mathrm{~kW}$ で単機, ブレード枚数は 3 枚, 回転数は $20.5 \mathrm{rpm}$ である。いずれの測定点でも騷音計の時間重み 付恃性 $\mathrm{F}$ を用いた騒音レベル $L_{\mathrm{A}, \mathrm{F}}$ は約 $1 \mathrm{~s}$ の周期で変 動している。このような周期的に変動する風車騒音を振 幅変調音あるいは swish 音（スウィッシュ音）と呼ぶ。 この周期の逆数はブレード通過周波数 (Blade Passing Frequency: BPF）とよばれ, 風車騒音を特徵付けるパラ メータのひとつである。レベル変動を見ると風車近傍の 測定点 $\mathrm{M} 0$ では $L_{\mathrm{A}, \mathrm{F}}$ の時間変動は $50 \sim 57 \mathrm{~dB}$ 程度で変 動幅は安定している。一方, 居住地域の M1, M5, M7 で は周期的な変動（振幅変調音）の他に，長周期で不規則 な変動（トレンド）がみられる。トレンドが生じる理由 としては風況の強さや分布の変化や，伝搬過程に打情 ゆらぎの影響が考兄らる。この例にみられるように居 住地域では一般には $L_{\mathrm{A}, \mathrm{F}}$ が $40 \mathrm{~dB}$ 以下となることも多い。 そのため, 風車騒音の測定に抢いては自動車走行騒音な ぞの測定対象外の騷音の影響を受けやすい。

\section{1 .2 対照地域での測定例}

風車地域と土地利用が類似した風力発電施設がない対 照地域の居住地域における夜間の環境騷音の測定例を 図 2 に示す (9)。ベースとなっている残留騷音（residual noise）は $25 \sim 27 \mathrm{~dB}$ 程度であり，90 パーセント時間率 騒音レベル $L_{\mathrm{A} 90}(26 \mathrm{~dB})$ 程度であるが, 環境騒音の評 価量として一般に用いられる $L_{\mathrm{Aeq}}$, は数百 $\mathrm{m}$ 離れた道 路の自動車走行騒音の影響を大きく受け，10 分間值 $L_{\mathrm{Aeq}, 10 \min }$ で $31 \mathrm{~dB}$ で, 自動車走行騒音などの測定対象外 の騒音の影響を受けやすいことが分かる。

\section{1 .3 風車地域と対照地域の等価騒音レベル}

戦略指定研究 I での 29 の風車地域の居住地域 164 測 定点に打ける風車騒音の $L_{\text {Aeq, night }}$ と, 16 の対象地域の 32 測定点の残留騒音の $L_{\text {Aeq,night }}$ の度数分布を図 3 に示す。

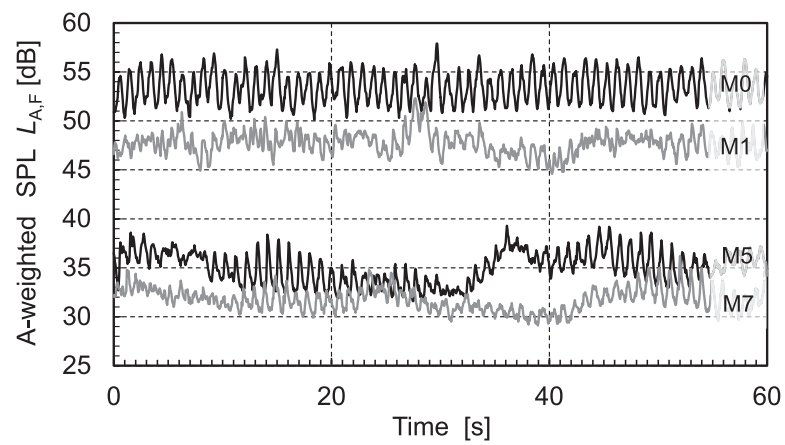

図1 風車騒音の騒音レベルの測定例。風車からの水平距離は, M0 : $37 \mathrm{~m}, \mathrm{M} 1: 173 \mathrm{~m}, \mathrm{M} 5: 563 \mathrm{~m}, \mathrm{M} 7: 1,152 \mathrm{~m}$ 。（日本音響 学会誌 2018;74(5):270-275 より転載)

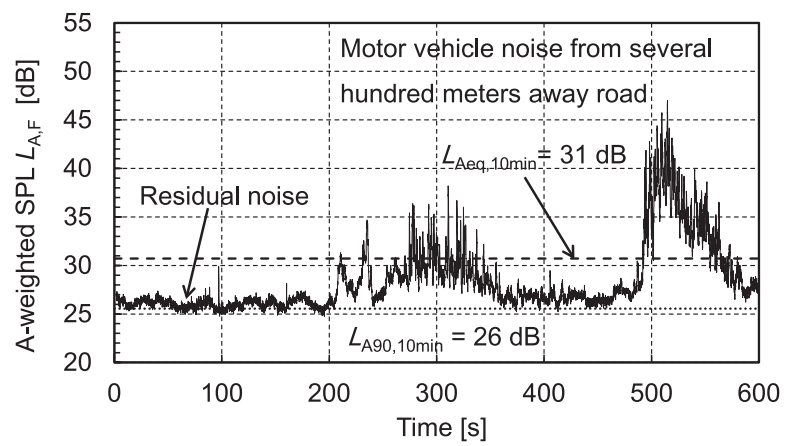

図 2 対象地域の騷音レベルの測定例

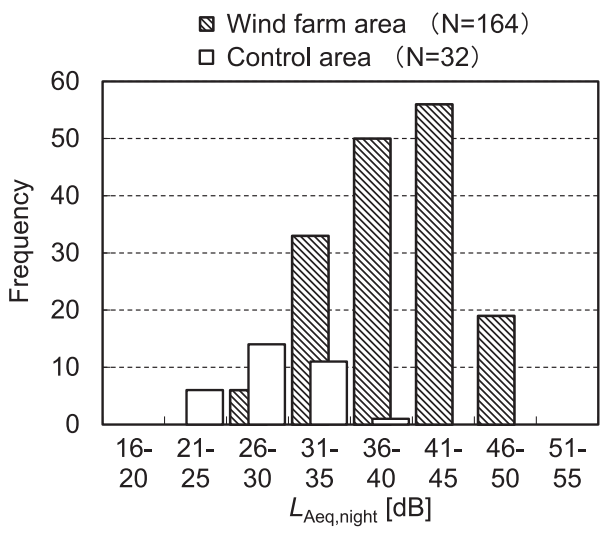

図 3 風車地域と対象地域の $L_{\text {Aeq,night }}$ の分布。（日本音響学会誌 2018;74(5):270-275 より転載） 
いずれも，自動車走行騒音等の一過性の騒音は除外音処 理している。な括，JIS Z 8731 「環境騒音の表示・測定 方法」では，音響的に明確に識別できる特定騒音を除い た残りの騒音を残留騒音としているが，本稿で用いて いる残留騒音は遠方の道路交通騷音や波の音など音源 がある程度識別でき, 準定常的に連続して観測される ベースとなる騒音も残留騒音に含んでいる。また風車騒 音には風力発電施設からの騒音の他に残留騒音も含んで いる。

風車騒音の $L_{\mathrm{Aeq}}$ は $26 \sim 50 \mathrm{~dB}$ 亿分布し, 最頻值は $41 \sim 45 \mathrm{~dB}$ のクラスで, $36 \sim 45 \mathrm{~dB}$ の 2 クラスに約 $2 / 3$ の測定点が含ま礼る。一方, 対照地域は $21 \sim 35 \mathrm{~dB}$ の 3 クラスに分布して和り, 風車地域の $L_{\mathrm{Aeq}}$ に比べて $10 \mathrm{~dB}$ 以上低い。ちなみに，環境基準で住居系の地域に相当す る $\mathrm{A}$ 類型抢よび $\mathrm{B}$ 類型の夜間の基準値 $\left(L_{\mathrm{Aeq}}\right)$ は $45 \mathrm{~dB}$ であるが, 風車地域の測定点の約 9 割は $45 \mathrm{~dB}$ 以下, 対 照地域についてはすべての測定点で $45 \mathrm{~dB}$ 以下である。

\section{2 風車騒音}

\subsection{1 $L_{\mathrm{Aeq}}$ の距離による变化}

戦略指定研究 II で調査対象とした島内について, 戦略 指定研究 I とII の測定値 $(3,5)$ を用いて, $L_{\text {Aeq,night }}$ と最 近接風車からの水平距離 $d[\mathrm{~m}]$ との関係を整理し図 4 に示す。騒音レベルの測定値には風車騒音の指向性の影 響や地形の影響も含まれるため, データはばらつくが, この測定例では平均的には $L_{\mathrm{Aeq}}$ は $-20 \log _{10} d$ の関係にあ り，打上そ $1 \mathrm{~km}$ 離孔ると $40 \mathrm{~dB}$ 以下となっている。

\subsection{2 $L_{\text {Aeq }}$ と $L_{\text {Ceq }}$ の対応}

風車騒音の問題では低周波数成分の影響を考慮して $\mathrm{C}$ 特性音圧レベルも重視すべきとの主張もある。そこで A 特性音压レベル $L_{\mathrm{Aeq}}$ と C 特性音圧レベル $L_{\mathrm{Ceq}}$ の対応を 図 5 に示寸 $(3,4)$ 。 $L_{\mathrm{Aeq}}$ と $L_{\mathrm{Ceq}}$ にはかなり高い相関関係 が見られる。な和, 風車騒音を含む各種環境騒音のラウ ドネスに関する聴感実験に打いて， $L_{\mathrm{A}}$ は Zwickerのラ ウドネスレベル $L L_{\mathrm{Z}}$ や Moore のラウドネスレベル $L L_{\mathrm{M}}$ と同等に適用可能であることが報告されている(10)。

\subsection{3 スペクトル}

29 の風車地域周辺の居住区域の 164 測定点に括ける 夜間の $1 / 3$ オクターブバンド音圧レベル $L_{p e q, \text { night }}(f)$ を重 敞書きして図 6 亿示す (4)。スペクトルの相対的な傾向 は類似して打り, 低周波数領域から高周波数領域にかけ て $-4 \mathrm{~dB} /$ オクターブの傾斜となっている。

これらの測定結果を評価するために, 図中にMoorhouse 他が提案している低周波音問題の有無を判別するための 基準曲線 (11)，抢よび ISO 389-7 で規定されている純音 に対する聴覚閾値を示す。基準曲線と測定結果全体を比 較すると, $20 \mathrm{~Hz}$ 以下の超低周波音領域ではすべての測 定結果が基準曲線を下回っている。これは, 風車周辺の 居住地域で一般的に観測される風車騒音の超低周波音領 域の成分は聴感上問題がないことを示唆している。この 点については戦略指定研究 I の聴感実験でも確認されて
いる(12)。な拉，対照地域の残留騒音のスペクトルは 測定点によってかなり異なるが，風車地域に比べてすべ ての周波数帯域で音圧レベルは大幅に低かった。

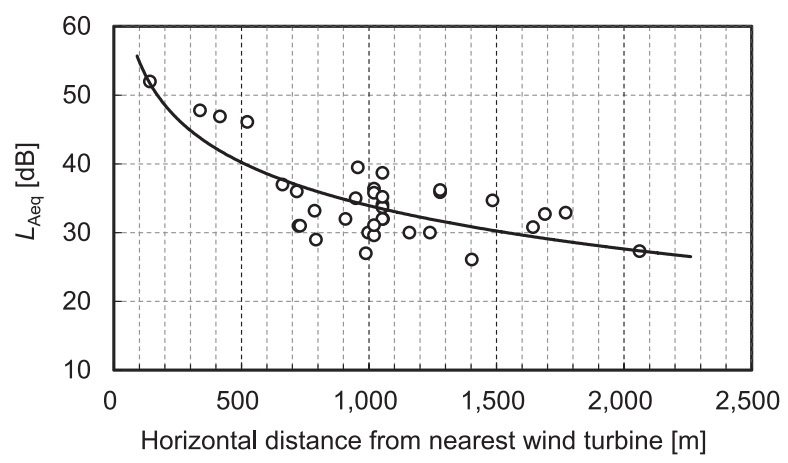

図 4 島内における風車騒音の $L_{\mathrm{Aeq}}$ と距離の対応

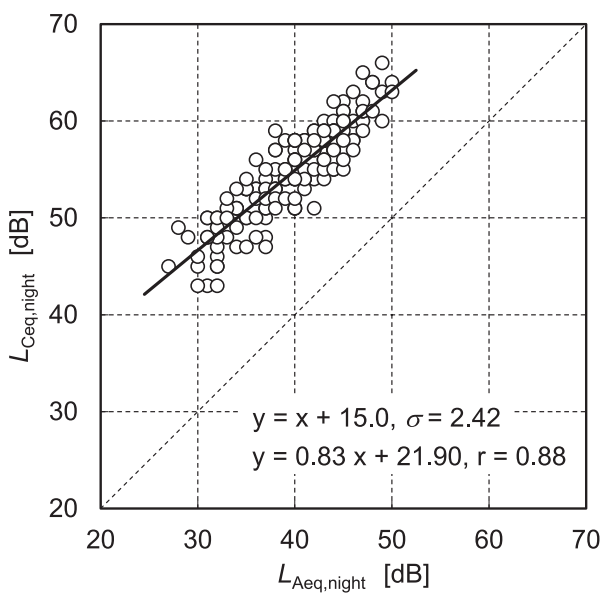

図 5 居住地域の風車騒音の $L_{\mathrm{Aeq}}$ と $L_{\mathrm{Ceq}}$ の対応。（日本音響学 会誌 2018;74(5):270-275 より転載)

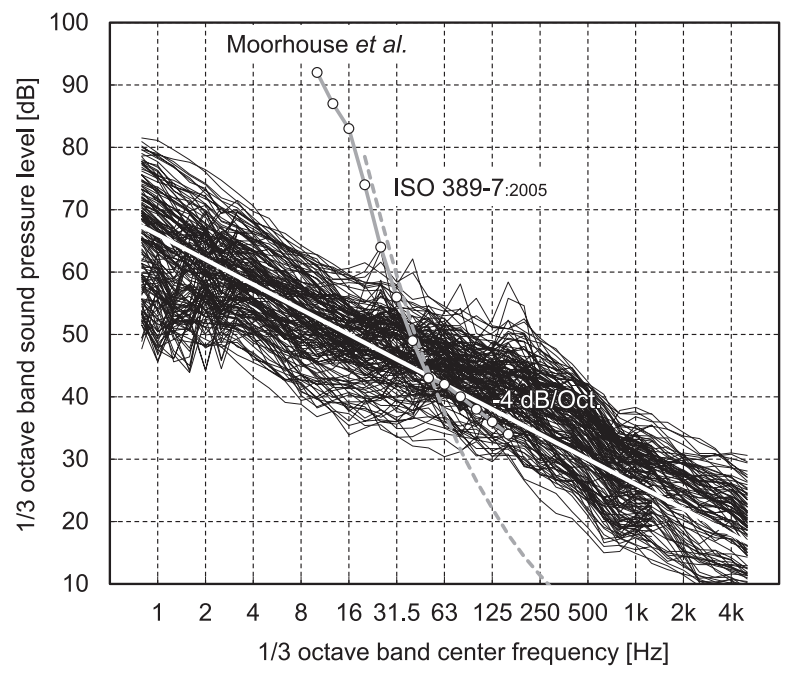

図 6 風車騒音のスペクトル $L_{p e q, n i g h t}(f)(N=164)$ 。(日本音響 学会誌 2018;74(5):270-275 より転載) 


\subsubsection{Noise emergence}

図 3 に示すよらに風力発電施設周辺の居住地域の施設 稼働時の $L_{\text {Aeq,night }}$ は $50 \mathrm{~dB}$ 以下であり, 多くは A 類型の 夜間の環境基準值 $45 \mathrm{~dB}$ 以下である。そのよらな状況に もかかわらず問題が発生する要因として, 稼働時と停止 時（あるいは建設前）における環境騒音の変化が考兄ら れる。

戦略指定研究 I の現地調査に扮いて, 風力発電施設稼 働時の風車騒音の等価騷音レベル $L_{\mathrm{Aeq}, \mathrm{WTN}, \mathrm{n}}$ と，風が弱く 施設が停止していたときの残留騒音の等価騒音レベル $L_{\text {Aeq,res, } n}$ の両方が測定できた 84 測定点の測定結果を最 近接風車からの水平距離で整理して図 7 に示す (13)。 いずれも対象外騒音の除外音処理を行って $L_{\mathrm{Aeq}}$ を算出 している。図 7 (a) は $L_{\text {Aeq,WTN,night }}$ と $L_{\text {Aeq, res,night }}$ の測定值 で, 図 7 (b) は $L_{\text {Aeq,WTN,night }}$ と $L_{\text {Aeq,res,night }}$ のレベル差で Noise emergence と呼ばれる評価量であり, 風車騒音に よる環境騒音の増加に相当する。 $L_{\text {Aeq,WTN,night }}$ は, 注とん どが $50 \mathrm{~dB}$ 以下であり，距離による減衰がみられる。 $L_{\text {Aeq,res,night }}$ は $40 \mathrm{~dB}$ 以下であり，多くの測定点では $25 \sim$ $35 \mathrm{~dB}$ 程度である。Noise emergence は風車に近い測定点 汪ど大きく, 最大で $26 \mathrm{~dB}$ 汪ど $L_{\mathrm{Aeq}}$ が増加している測定 点もある。また $L_{\text {Aeq,res,night }}$ が小さい測定点ほど, Noise

(a)

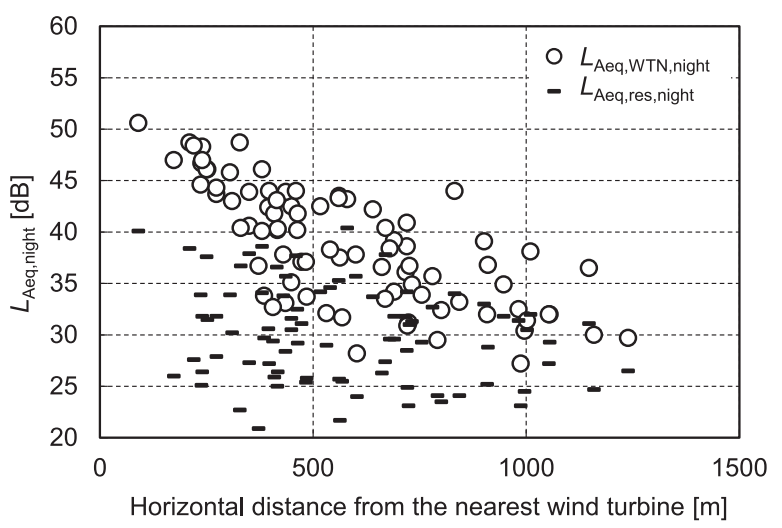

(b)

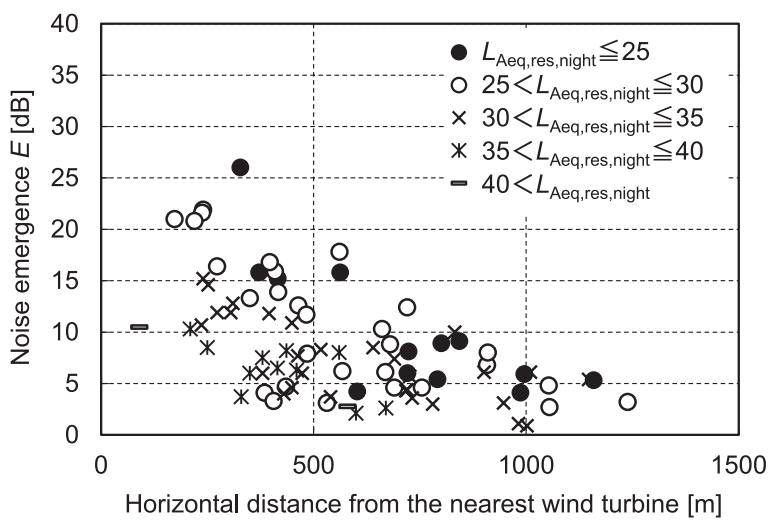

図 7 施設稼動時と停止時の $L_{\text {Aeq }}(N=84)$ 。(a) $L_{\text {Aeq,nighto (b) }}$ Noise emergence $E$ (風車騷音と残留騒音の $L_{\mathrm{Aeq}}$ のレベル差)。 （日本音響学会誌 2018;74(5):270-275 より転載） emergence が大きくなる傾向にある。なお，距離が離れ ると Noise emergence が小さくなるが, これは距離が離 れると $\mathrm{S} / \mathrm{N}$ の関係で風車騒音が測定できない測定点が 多かったためである。

この結果は，風車騒音の評価に打いては，施設稼働時 と停止時のレベル差が重要であることを示唆するもので ある。わが国の風車騷音の評価 $(6,7)$ では，一般には風 力発電施設建設前や停止時に拈ける施設が発電可能な風 況下（有効風速範囲）での残留騒音 $L_{\mathrm{Aeq}, \mathrm{res}}$ に $5 \mathrm{~dB}$ 加算 した值を風車騷音の指針值としている。また同様な取り 扱いはイギリスなどのいくつかの国・地域にもみられる （14）。な打，図７（a）に示す残留騒音は，風が弱く風 車が停止していたときの騒音レベルであり，指針值で用 いる発電できる程度の有効風速範囲での残留騷音とは異 なる。

\section{2 .5 振幅変調音}

風車騒音の特徵の一つに図 1 に示すような周期的に変 動する振幅変調音がある。これは風車のブレードの高速 移動に伴い発生する空力騒音であり，ブレードの通過に 伴って変動が生じる。このような周期性が強い音は聴覚 心理的にきわめて気になり，アノイアンスを高める原因 となる。図 8 は風車騒音の $1 / 1$ オクターブバンドでの周 波数分析結果である。図には周波数重久付恃性 $\mathrm{A}$ 拈 よびCでの音压レベル $L_{\mathrm{A}}$ 扰よび $L_{\mathrm{C}}$ b併せて示す。レ ベル変動は $125 \mathrm{~Hz} \sim 1 \mathrm{kHz}$ の 4 オクターブバンドで明 確にみられる。また $L_{\mathrm{A}}$ の方が $L_{\mathrm{C}}$ よりもレベル変動は顕 著に表れている。

振幅変調音の評価のためには，変調の程度を定量的に 把握することが重要で，いくつかの方法 (15) が提案さ れているが，戦略指定研究 I でも図 9 に示寸実務的な方 法を提案している(8)。これは騒音レベルの長周期で不 規則なトレンドを騒音計の時間重み付け特性 S を用い た騒音レベル $L_{\mathrm{A}, \mathrm{S}}$ で代表させ，時間重み付け特性 $\mathrm{F}$ を用

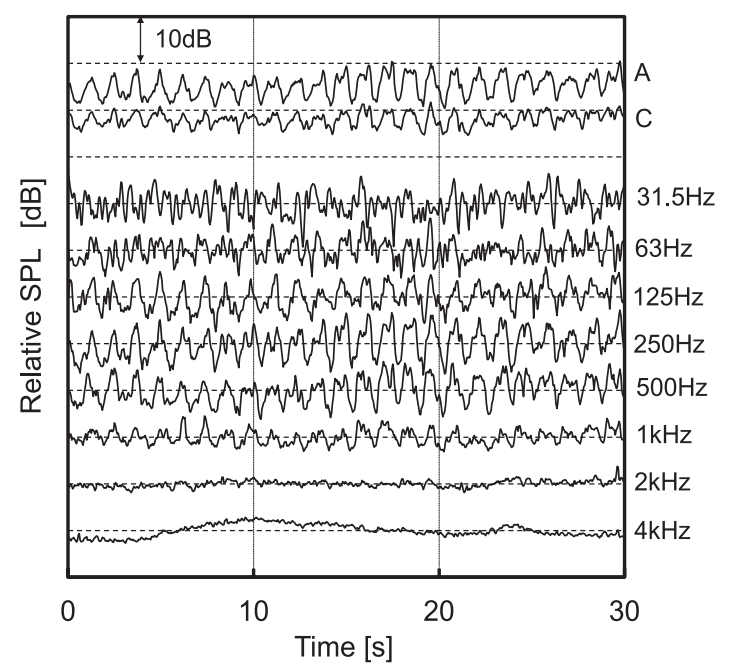

図 8 音圧レベルの時間変動の例（1/1 オクターブバンド SPL, 打よび $\left.L_{A}, L_{C}\right)$ 
いた騒音レベル $L_{\mathrm{A}, \mathrm{F}}$ とのレベル差を振幅变調成分 $\Delta L_{\mathrm{A}}$ と し, $\Delta L_{\mathrm{A}}$ の 90 パーセントレンジ幅 $\Delta L_{\mathrm{A}, 5}-\Delta L_{\mathrm{A}, 95}$ を変調深 さ $D_{\mathrm{AM}}$ とし振幅変調音の変動の大きさを求める方法で ある。

この方法をわが国の 18 風車地域 81 測定点での測定 データに適用し， $D_{\mathrm{AM}}$ の分布を整理した結果を図 10 に 示す。 $D_{\mathrm{AM}}$ は $1 \sim 5 \mathrm{~dB}$ に分布し, 最頻值は 2.0-2.4 dB であった。振幅変調が $2 \mathrm{~dB}$ を超えると変動感を感じる ため (16), 多くの測定点で何らかの変動感を感じてい る。な拝，図９に示す方法は簡便な方法であるが，文献 15 に示されている精緻な方法による変動幅の算出值と の間にはよい対応があることを報告している（17）。

(a)

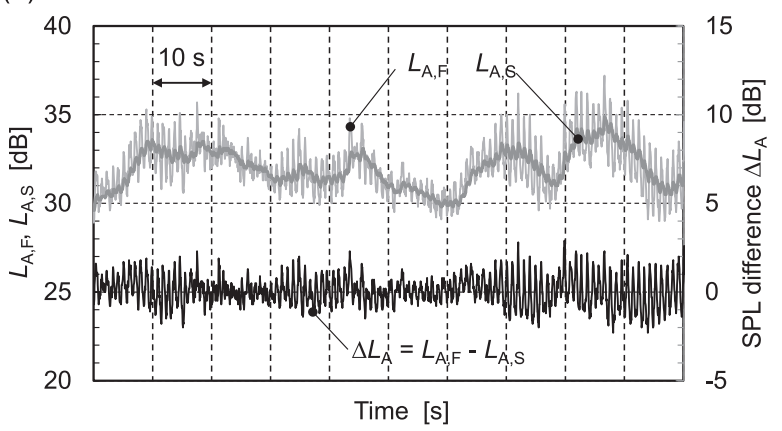

(b)

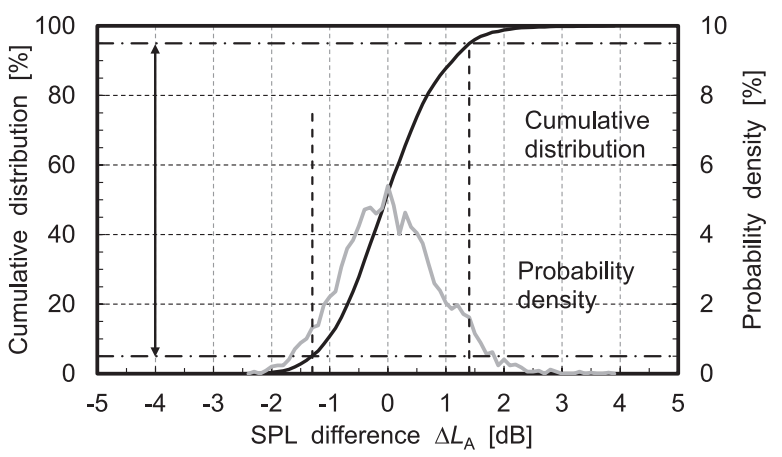

図 9 振幅変調音の変調の程度の分析方法。(a) 風車騒音の $L_{\mathrm{A}, \mathrm{F}}, L_{\mathrm{A}, \mathrm{S}}$ 打よびレベル差 $\Delta L_{\mathrm{A}}$ （b）変調深さ $D_{\mathrm{AM}}$ の算出。（日 本音響学会誌 2018;74(5):270-275 より転載)

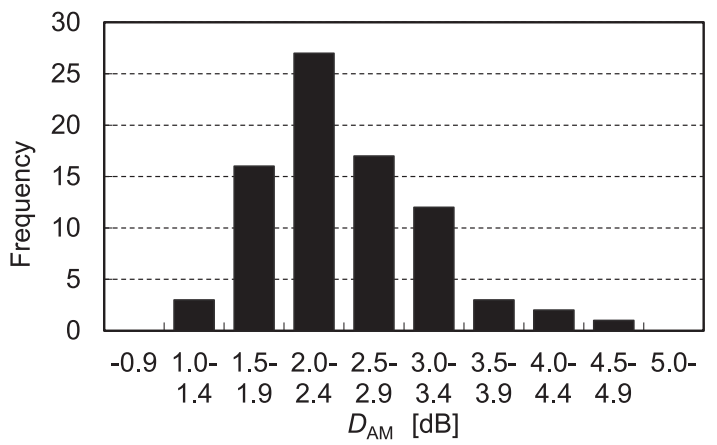

図 10 変調深さ $D_{A M}$ の分布 (18 施設 81 測定点)。(日本音響 学会誌 2018;74(5):270-275 より転載)

\subsection{6 純音性騒音}

風車騒音に寄せられる苦情のひとつとして，広帯域騒 音の中に卓越した純音性の成分が含まれる純音性騒音が ある。これはナセル内に収納されている増速機などの回 転系の機械から発生する騒音である。図４に示した測定 結果の中にもそのよらなデータがいくつか含まれている が，図 11 に純音性騷音を含む風車騒音を狭帯域周波数 分析した結果を示す (18)。135 Hz 付近にはっきりとし た卓越成分がみられ，前後の音圧レベルよりも $15 \mathrm{~dB}$ 程 度大きい。このような純音性成分が強く含まれていると アノイアンスを高める一因となる。純音性騒音の評価方 法としては, ISO 1996-2 の規定による評価方法があるが, 現在, その妥当性の検証も含めて研究が進められている。

\section{3 静穏地域における環境騒音}

風力発電施設が建設される地域は, 一般には静穏な地 域であることが多く，ベースとなる残留騒音に一過性の 騒音が重畳したレベル変動となる。戦略指定研究 IIで測 定した島内 72 地点の測定点における騷音レベルの瞬時 值を用いて，レベル分布を整理した結果を図 12 に示す （19）。測定点により絶対值はばらついているが，騒音レ ベルの瞬時値の分布は相対的に類似している。騷音レベ ルの瞬時值の 10 パーセント值と 50 パーセント值のレベ 儿差は拈よそ $1.5 \mathrm{~dB}$ であり，80 パーセント前後から一 過性の騷音の影響を受けて分布が变化する様子がうかが える。このとを踏まえると長時間を占める残留騒音が，

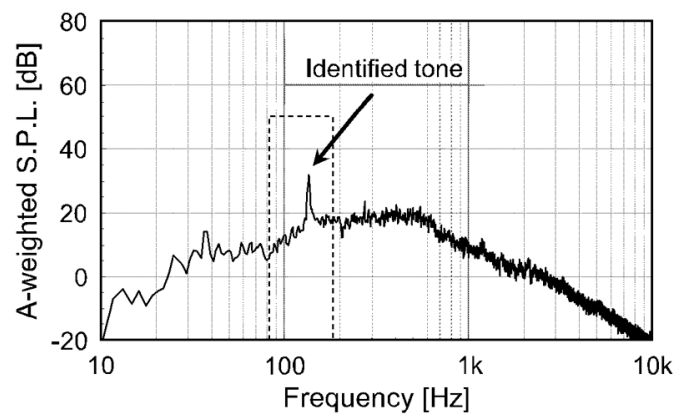

図 11 風車騒音に含まれる純音性騒音の例

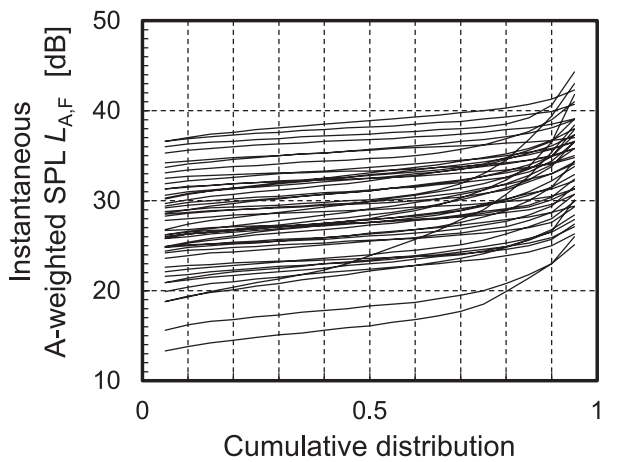

図 12 騒音レベル $L_{\mathrm{A}, \mathrm{F}}$ の瞬時值の分布（調査した島内の 57 測 定点，夜間) 
風車騒音により大きく変化することが問題の主要な要因 と考兄ら机る。な抏，この上らな分布は，都市内の幹線 道路から離れた住宅地でも見られる。

\section{$3.4 L_{\mathrm{A} 90}$ からの $L_{\mathrm{Aeq}}$ の推計}

前述のように，風車騒音や残留騒音の測定に扎いては 等価騒音レベル $L_{\mathrm{Aeq}}$ は一過性の騒音の影響を受けやす いため，分析に多大な労力を要する。一方，騒音レベル のベースに相当する 90 パーセント時間率騒音レベル $L_{\mathrm{A} 90}$ は一過性の騒音の影響は受けにくい。図 13 に, 戦 略指定研究 I で測定した振幅変調音が聴感上で確認でき る 18 の風力発電施設周辺の居住地域の 81 測定点の測定 データを用いて，除外音処理して算出した風車騒音の $L_{\text {Aeq,WTN }}$ と除外音処理を行わずに算出した総合騒音の $L_{\text {Aeq,total }}$ の対応, 抢よび $L_{\text {Aeq,WTN }}$ 総合騒音の 90 パーセ ント時間率騷音レベル $L_{\mathrm{A} 90, \text { total }}$ の対応を示す $(9)$ 。一過 性の騷音の影響で，除外音処理の有無での $L_{\text {Aeq,WTN }}$ と $L_{\text {Aeq,otal }}$ には最大で約 $25 \mathrm{~dB}$ の差がみられる。一方,

(a)

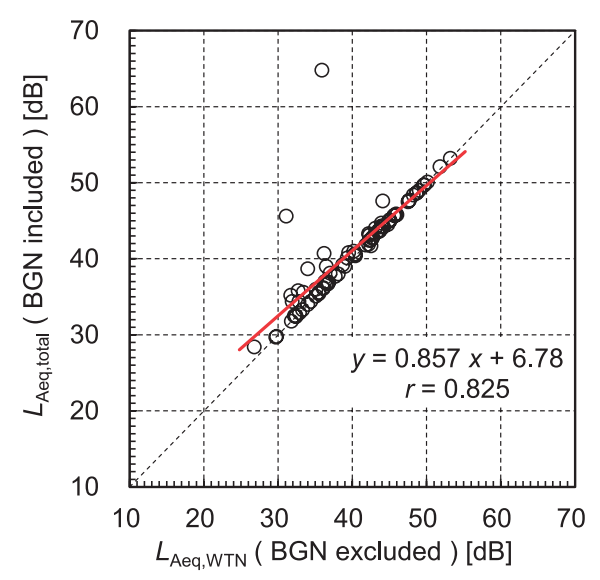

(b)

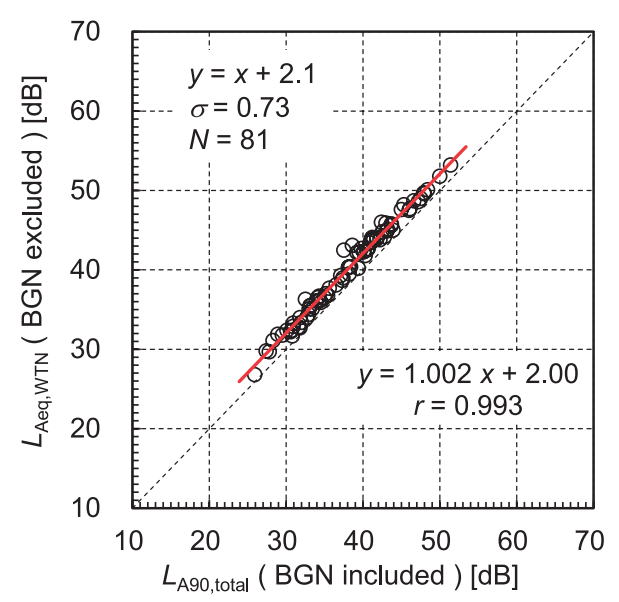

図 13 風車騒音の測定値の対応 (81 測定点)。(a) 除外音処理 の有無による $L_{\text {Aeq }}$ の比較。(b) $L_{\text {Aeq,WTN }}$ (除外音処理) と $L_{\text {A90,total }}$ (除外音処理無し) の対応。（日本音響学会誌 2018;74(5):270275 より転載)
$L_{\mathrm{Aeq}, \mathrm{WTN}}$ と $L_{\mathrm{A} 90, \text { total }}$ の相関は非常に高く, 両者のレベル差 は，平均值が $2.1 \mathrm{~dB}$ ，標準偏差が $0.73 \mathrm{~dB}$ である。この ことは除外音処理を行わずに算出した総合騒音の $L_{\mathrm{A} 90 \text {. total }}$ から $L_{\mathrm{Aeq}, W T N}$ が精度よく推計できることを示している。

図 14 は, 風車地域の施設停止時の測定データ, 対照 地域の測定データ, 拉よび風力発電施設がない各種地域 （都市部や工業系地域を含む）の測定データを用いて， 除外音処理して算出した残留騷音の $L_{\text {Aeq,resid }}$ と総合騒音 の $L_{\text {Aeq, total }}$ の対応，特よび $L_{\text {Aeq, resid }}$ と $L_{\text {A90, total }}$ の対応である (文献 13 の測定データに追加)。背景騒音の影響で，除 外音処理有無での $L_{\text {Aeq,resid }}$ と $L_{\text {Aeq, toal }}$ は最大で約 $20 \mathrm{~dB}$ の 差がみられる。一方， $L_{\text {Aeq, resid }}$ と $L_{\mathrm{A} 90 \text {, total }}$ の相関は非常に 高く, 両者のレベル差は, 平均值が $1.6 \mathrm{~dB}$, 標準偏差が $0.74 \mathrm{~dB}$ である。

風車騒音も残留騒音も，実測時間の総合騒音の $L_{\mathrm{A} 90, \text { total }}$ に $2 \mathrm{~dB}$ 加光た值に近い。な怙イギリスでの調査結果で は $L_{\mathrm{Aeq}, \mathrm{WTN}}$ と $L_{\mathrm{A} 90, \mathrm{WTN}}$ のレベル差は $1.5 \sim 2.5 \mathrm{~dB}$ である ことが報告されて打り（20），また一般には， $L_{\mathrm{A} 90, \mathrm{WTN}} \fallingdotseq$

(a)

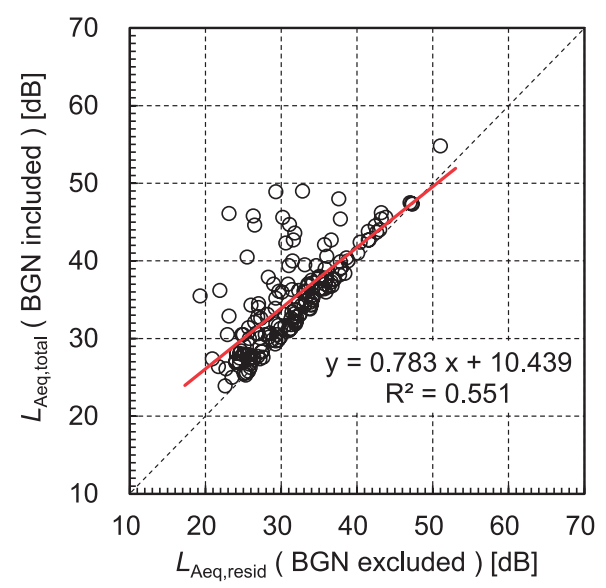

(b)

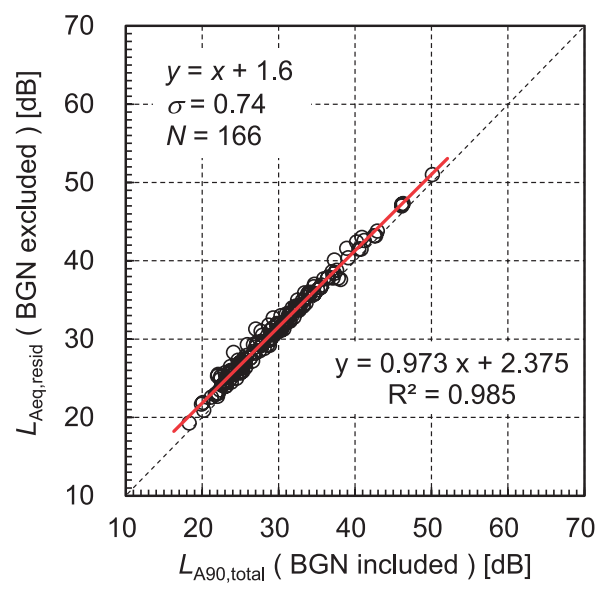

図 14 残留騒音の測定值の対応（166 測定点)。(a) 除外音処 理の有無飞よる $L_{\text {A eq }}$ の比較。(b) $L_{\text {Aeq, resid }}$ (除外音処理) と $L_{\text {A } 00 \text { total }}$ (除外音処理無し）の対応。（日本音響学会誌 2018;74(5): 270-275より転載) 
$L_{\mathrm{A} 90, \text { total }}$ であることから $(9,13)$ ， イギリスの報告と同様 であった。このことから, 時間と労力を有する除外音処 理をしなくても，総合騒音の $L_{\mathrm{A} 90, \text { total }}$ を測定することで $L_{\mathrm{Aeq}, \mathrm{WTN}}$ と同等な值が得られ, またこの方法は除外音処 理に拈ける判別の個人差に関係しないため, 標準的な測 定方法として有効であるといえる。

\section{4.おわりに}

環境省の戦略指定研究で実測した結果に基づき, 風力 発電施設周辺の居住地域に抢ける風車騒音と残留騒音の

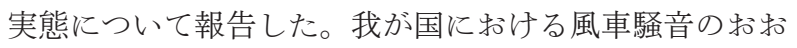
よその実態が把握できたと考えられる。ただし，近年の 風力発電施設は大型化に向かって扣り, 調査していない よらな大型施設も建設されつつある。継続した調査が望 まれる。また, 純音性騷音等の実態やその評価方法につ いても，実務的な評価方法の研究が望まれる。

なお，本稿は環境省環境研究総合推進費で実施した研 究 $(3,5)$ の一部である。

\section{本報告に関する利益相反はない。}

\section{文献}

（1）環境省. 騷音に係る環境基準について（平成 24 年 3 月).

（2）環境省. 騷音に係る環境基準の評価マニュアル（平成 27 年 10 月).

(3) 環境省. 平成 22-24 年度環境研究総合推進費研究課題 $\lceil\mathrm{S} 2-11$ 風力発電等による低周波音の人への影響評価 に関する研究」報告書.

(4) Tachibana H, Yano H, Fukushima A, Sueoka S. Nationwide field measurements of wind turbine noise in Japan. Noise Control Engr 2014;62:90-101.

（5）環境省. 風力発電等による低周波音・騒音の長期健康 影響に関する疫学研究. 平成 27 年度 環境研究総合 推進費終了成果報告書 (5-1307)。

（6）環境省. 風力発電施設から発生する騷音等への対応に ついて (平成 28 年 11 月).

（7）環境省. 風力発電施設から発生する騒音等測定マニュ
アル (平成 29 年 5 月).

( 8 ) Fukushima A, Yamamoto K, Uchida H, Sueoka S, Tachibana H, et al. Study on the amplitude modulation of wind turbine noise: Part 1-Physical investigation. Proc Inter-Noise 2013.

( 9 ) Fukushima A, Kobayashi T, Tachibana H. Practical measurement method of wind turbine noise. Proc Wind Turbine Noise 2015

(10) Sakamoto S, Yokoyama S, Tsujimura S, Tachibana H. Loudness evaluation of general environmental noise containing low frequency components. Proc Inter-Noise 2013.

(11) Moorhouse AT, Waddington DC, Adams MD. A procedure for the assessment of low frequency noise complaints. J Acoust Soc Am 2009;126:1131-1141.

（12）横山 栄，坂本慎一，橘 秀樹. 風車騒音の低周波数 成分の可聴性に関する聴感実験. 音講論 (2014.9).

(13) Fukushima A, Tachibana H, Nameki M. Assessment of wind turbine noise and residual noise in immission areas around wind power plants. Proc Inter-Noise 2015.

（14）橘 秀樹. 諸外国に抢ける風車騒音に関するガイドラ イン。 日本音響学会誌 2015;71:199-200.

(15) Institute of Acoustics IOA Noise Working Group (Wind Turbine Noise) Amplitude Modulation Working Group Final Report. A Method for Rating Amplitude Modulation in Wind Turbine Noise, Version 1 (2016.8).

(16) Yokoyama S, Sakamoto S, Tachibana H. Study on the amplitude modulation of wind turbine noise: part 2-Auditory experiment. Proc Inter-Noise 2013.

(17) Fukushima A, Tachibana H. Comparison of the 1OA method and Japanese F-S method for quantitative assessment of amplitude modulation of wind turbine noise- $\mathrm{A}$ study based on the field measurement results in Japan. Proc Wind Turbine Noise 2015.

(18) Kobayashi T, Yokoyama S, Fukushima A, Ohshima T, Sakamoto S, Tachibana H. Assessment of tonal components contained in wind turbine noise in immission areas. Proc Wind Turbine Noise 2015.

（19）太田達也, 福島昭則, 原 邦夫, 森松嘉孝, 石竹達也. 静穏地域に打汗る環境騒音の構成. 日本騒音制御工学 会秋季研究発表会, p. 125-128 (2015.9).

(20) Institute of Acoustics. A good practice guide to the application of ETSU-R-97 for the assessment and rating of wind turbine noise (2013.5). 